https://helda.helsinki.fi

\title{
Denitrification in the River Estuaries of the Northern Baltic Sea
}

\section{Silvennoinen, Hanna}

2007

Silvennoinen , H , Hietanen , S , Liikanen , A , Stange , C F , Russow , R , Kuparinen , J \& Martikainen , P J 2007 , ' Denitrification in the River Estuaries of the Northern Baltic Sea ', Ambio, vol. 36 , no. 2-3, pp. 134-140 .

http://hdl.handle.net/10138/29415

submittedVersion

Downloaded from Helda, University of Helsinki institutional repository.

This is an electronic reprint of the original article.

This reprint may differ from the original in pagination and typographic detail.

Please cite the original version. 
1 Denitrification in the river estuaries of the northern Baltic Sea

2 Hanna Silvennoinen*1, Susanna Hietanen ${ }^{2}$, Anu Liikanen, C. Florian Stange ${ }^{3}$, Rolf

3 Russow $^{3}$, Jorma Kuparinen ${ }^{2}$ and Pertti J. Martikainen ${ }^{1}$

4

$5{ }^{1}$ Department of Environmental Sciences, University of Kuopio, Research and

6 Development Unit of Environmental Health, P.O. BOX 1627, FIN--70211 Kuopio,

$7 \quad$ Finland.

$8{ }^{2}$ Department of Biological and Environmental Sciences, Division of Aquatic Sciences,

9 University of Helsinki, P.O. BOX 65, FIN-00014 University of Helsinki, Finland

$10{ }^{3}$ Helmholtz Centre for Environmental Research - UFZ, Department of Soil Physics,

11 Theodor-Lieser-Str. 4, D-03120 Halle/Saale.

12

13 Number of words in the text 4996

14

15

16

17

18

19

20

21

22

23

24

25 
1 Biographies of authors

2 *Corresponding author, Hanna Silvennoinen ${ }^{1}$ (hanna.silvennoinen@uku.fi, tel. +358

$317163591) \mathrm{MSc}$, is a $\mathrm{PhD}$ student specialising on nitrogen cycling in rivers at the

4 Department of Environmental Sciences, University of Kuopio.

6 Dr. Susanna Hietanen ${ }^{2}(\mathrm{PhD}$ in limnology) (susanna.hietanen@helsinki.fi, tel. +358

$7 \quad 191$ 57824) is a post doctoral researcher at the Department of Biological and

8 Environmental Sciences, Division of Aquatic Sciences, at the University of Helsinki.

9 She has several years of experience in microbial ecology both in benthic and pelagic

10 environments. She is fully competent in stable and radioactive isotope methods

11 (denitrification, anammox, bacterial production) and micro- and minielectrode

12 techniques for measuring oxygen profiles and nitrate in sediment. Her current field of

13 research is the benthic denitrification and the factors controlling it in the coastal areas

14 of the Baltic Sea. She has also launched studies on benthic respiration and anammox

15 in The Baltic Sea on 2003. Her field studies have been supplemented with

16 experimental approaches using mesocosms including manipulations with sedimenting

17 algal biomass, oxygen concentration changes, sediment structure changes and altered

18 bioturbation.

20 Dr. Anu Liikanen ${ }^{1}$ (PhD in environmental sciences) (anu.liikanen@uku.fi, tel. +358

2140 7238551) is a post doctoral researcher at the Department of Environmental

22 Sciences, University on Kuopio, Finland. She has expertise in studying

23 biogeochemical cycles of elements carbon, nitrogen and phosphorus in aquatic

24 sediments and wetlands. Since her dissertation on "Greenhouse gas and nutrient

25 dynamics in lake sediment and water column in changing environment" she has 
1 studied cycling of nutrients and greenhouse gases in constructed wetlands, estuarine

2 wetlands and river water.

4 Prof. C. Florian Stange ${ }^{3}$ (florian.stange@ufz.de, tel. +49 345-558-5418) is

5 geoecologist and both the head of the working group Stable Isotopes and

6 Biogeochemical Cycles of the Helmholtz Centre for Environmental Research - UFZ

7 and junior professor at the Martin-Luther-University Halle-Wittenberg, Germany. He

8 has worked for nearly 10 years on modelling of soil processes. He started with

9 modelling of herbicide transport in macroporous soils and since his $\mathrm{PhD}$ work at the

10 Fraunhofer Institute for Atmospheric Environmental Research he is involved in

11 investigation of production, consumption and transport of trace gases in soils. Topics of

12 his current research: separation of trace gas production during heterotrophic and

13 autotrophic nitrification, studies regarding the emission ratio of $\mathrm{N}_{2} \mathrm{O} / \mathrm{N}_{2}$ influenced by

14 soil parameters and process oriented modeling.

16 Dr. Rolf Russow ${ }^{3}$ (PhD (Dr.rer.nat.) in physical chemistry) (isotopes@russow-lpz.de, 17 rolf.russow@ufz.de, tel.+49 345-558-5413) Till his retirement in 2004 he was a

18 senior scientist at the Department of Soil Science of the UFZ Centre for

19 Environmental Research Leipzig-Halle, Germany, and specialized in the application

20 of radionuclides and stable isotopes in chemistry, biochemistry and life sciences.

21 Topics of his research: kinetic and heterogeneous catalysis in organic chemistry,

22 biological nitrogen fixation, $\mathrm{N}$ transformation processes in biological systems, trace

23 gases formation and exchange between soil/water and atmosphere, stable isotope

24 analysis. Currently he works as a scientific consultant for stable isotope application 25 and analysis. 
$1 \quad$ Prof. Jorma Kuparinen $^{2}$ (jorma.kuparinen@helsinki.fi, tel. +358 57820) has a

2 professorship at the University of Helsinki in marine biology. His research experience

3 extends over the last 27 years. His main interest has been on microbial ecology with

4 specific focus on the carbon cycle. His field studies have often been supplemented

5 with experimental studies in microcosm including manipulations with environmental

6 factors such as nitrogen, phosphorus and carbon. Rate measurements, based on

7 isotope incorporation techniques $\left({ }^{3} \mathrm{H},{ }^{14} \mathrm{C},{ }^{32} \mathrm{P}\right.$ and $\left.{ }^{15} \mathrm{~N}\right)$ as well as biomass estimated

8 by various microscopic techniques have been applied and developed in the studies.

10 Prof. Pertti J. Martikainen ${ }^{1}$ (Pertti.Martikainen@uku.fi, tel. +358 17163586) has a

11 professorship at the University of Kuopio (Department of Environmental Sciences) in 12 biogeochemistry and environmental microbiology, and is the head of the 13 Biogeochemistry Research Group. His speciality is in biogeochemistry of carbon 14 dioxide, methane and nitrous oxide in boreal terrestrial and aquatic ecosystems, and 15 carbon and methane dynamics of tundra. He has 180 articles in international refereed 16 journals on microbial ecology and biogeochemistry of greenhouse gases. 


\section{Abstract}

2 Estuaries have been suggested to have an important role in reducing the nitrogen load

3 transported to the sea. We measured denitrification rates in six estuaries of the

4 northern Baltic Sea. Four of them were river mouths in the Bothnian Bay (northern

5 Gulf of Bothnia), and two were estuary bays, one in the Archipelago Sea (southern

6 Gulf of Bothnia) and the other in the Gulf of Finland. Denitrification rates in the four 7 river mouths varied between 330 and $905 \mu$ mol $\mathrm{N} \mathrm{m}^{-2} \mathrm{~d}^{-1}$. The estuary bays at the 8 Archipelago Sea and the Gulf of Bothnia had denitrification rates from 90 to 910 $9 \mu \mathrm{mol} \mathrm{N} \mathrm{m} \mathrm{N}^{-1}$ and from $230-320 \mu \mathrm{mol} \mathrm{N} \mathrm{m}^{-2} \mathrm{~d}^{-1}$, respectively. Denitrification 10 removed $3.6-9.0 \%$ of the total nitrogen loading in the river mouths and in the 11 estuary bay in the Gulf of Finland, where the residence times were short. In the 12 estuary bay with a long residence time, in the Archipelago 13 Sea, up to $4.5 \%$ of nitrate loading and $19 \%$ of nitrogen loading were 14 removed before entering the Sea. According to our results, the sediments of the fast 15 flowing rivers and the estuary areas with short residence times have a limited capacity 16 to reduce the nitrogen load to the Baltic Sea.

\section{Introduction}

19 The Baltic Sea is a large brackish water basin suffering from eutrophication. The 20 drainage area of the sea is four times larger than the sea itself, and populated by 85 21 million people. The Gulf of Bothnia is the northernmost basin of the Baltic Sea.

22 Shallow sills at the Archipelago Sea prevent the inflow of the more saline water. This 23 isolation from the rest of the Baltic Sea, together with the large freshwater inflow, 24 makes the area less saline than the northern Baltic Sea in general. Primary production 25 in the Gulf of Bothnia is phosphorus limited and, unlike the rest of the Baltic Sea, The 
1 Gulf is in an ecologically good state. Annual nitrogen (N) loading to the Gulf was 74

2100 tons in 2000 [1]. Since the 1990's, increasing nitrate concentrations have been

3 measured especially in Finnish coastal waters rivers entering the Gulf of Bothnia [2].

5 The Gulf of Finland is an estuary-like area, directly connected to the Baltic Proper at

6 its western end, and under the influence of the river Neva at the eastern end. In

7 contrast to the Gulf of Bothnia, it is heavily eutrophied. Nutrient loading into the Gulf

8 of Finland has been decreasing in the last decades, due to the active protection of the

9 Gulf of Finland and economic depression in the surrounding states Russia and Estonia

10 [3]. However, 120000 tons of N still enter the Gulf of Finland every year [4].

12 The fate of $\mathrm{N}$ entering the aquatic ecosystem depends on the prevailing conditions.

13 Organic $\mathrm{N}$ compounds are decomposed by microbes to ammonium $\left(\mathrm{NH}_{4}{ }^{+}\right)$, which can

14 be taken up by primary producers, or nitrified by bacteria to nitrate $\left(\mathrm{NO}_{3}{ }^{-}\right) . \mathrm{NO}_{3}{ }^{-}$can

15 be taken up or processed further in denitrification, anaerobic ammonium oxidation 16 (anammox) or dissimilatory $\mathrm{NO}_{3}{ }^{-}$reduction to $\mathrm{NH}_{4}{ }^{+}$(DNRA). Of these processes, 17 DNRA reduces $\mathrm{NO}_{3}{ }^{-}$back to $\mathrm{NH}_{4}{ }^{+}$, still available to other organisms. $\mathrm{N}$ taken up by 18 primary producers is bound to the biomass and later released back to the water 19 ecosystem. Denitrification (the sequential reduction of $\mathrm{NO}_{3}{ }^{-}$to nitrogen gas $\left(\mathrm{N}_{2}\right)$ ) and 20 anammox (oxidizing of $\mathrm{NH}_{4}^{+}$with nitrite $\left(\mathrm{NO}_{2}{ }^{-}\right)$to $\mathrm{N}_{2}$ ) are the only processes that 21 remove $\mathrm{N}$ permanently from the system. Denitrification, but not anammox, may have 22 an effect on global warming via the gaseous intermediate, nitrous oxide $\left(\mathrm{N}_{2} \mathrm{O}\right) . \mathrm{N}_{2}$, the 23 end product of denitrification, is abundant (78\%) in the atmosphere, whereas the 24 intermediate $\mathrm{N}_{2} \mathrm{O}$ is an effective greenhouse gas. The ratio of these gases produced by 25 denitrification in aquatic ecosystems is affected by several environmental factors, e.g. 
1 temperature, oxygen concentration and $\mathrm{NO}_{3}{ }^{-}$availability $[5,6,7]$. In sediments, usually

2 less than $5 \%$ of the gases produced in denitrification is $\mathrm{N}_{2} \mathrm{O}$ [8]. Nevertheless, it has

3 been suggested that in areas with high $\mathrm{NO}_{3}{ }^{-}$load, such as river mouths and estuaries,

4 production of $\mathrm{N}_{2} \mathrm{O}$ may be enhanced [8].

6 Denitrification has been estimated to remove $30 \%$ of the annual $\mathrm{N}$ loading in the Gulf

7 of Finland [9], and $23 \%$ in the Bothnian Bay [10]. Both of these estimates are based

8 on results from the depositional areas of the open sea. Estuaries have been suggested

9 to be effective sinks of $\mathrm{N}$ loading, reducing the load transported to the sea $[8,11,12]$.

10 The few estimates of the filtering capacity published so far from the northern Baltic

11 Sea seem to challenge this view (Hietanen S. and Kuparinen J. Seasonal and short-

12 term variation in denitrification and anammox at a coastal station on the Gulf of

13 Finland, Baltic Sea. Submitted) [13,14]. More data is needed to understand the

14 capacity of these ecosystems to reduce the $\mathrm{N}$ load entering the sea.

16 We measured denitrification rates in six estuaries of the northern Baltic Sea. Four of 17 them were river mouths in the Bothnian Bay (northern Gulf of Bothnia), and two were 18 estuary bays, one in the Archipelago Sea (southern Gulf of Bothnia) and the other in 19 the Gulf of Finland (Figure 1). Two projects, both part of the Baltic Sea Research 20 Programme (BIREME) of the Academy of Finland (2003-2006) contributed to this 21 work. Two ${ }^{15} \mathrm{~N}$ methods were applied in the studies. The CoastGas project (University 22 of Kuopio, Finland and UFZ Leipzig-Halle, Germany) measured $\mathrm{NO}_{3}{ }^{-}$removal in the 23 river mouths using a flow-through method, and the SEGUE-N project (University of 24 Helsinki, Finland) measured denitrification in the two estuary bays using the isotope 
1 pairing technique [15]. The rates measured were compared to the local $\mathrm{N}$ loading, in

2 order to estimate the filtering capacity of the estuaries.

42 Materials and Methods

$5 \quad$ Area descriptions

6 In the Bothnian Bay, the study sites were at river mouths of Temmesjoki, Siikajoki,

7 Pyhäjoki and Kalajoki (Figure 1A). The catchments of these rivers contain mainly 8 peatlands and forests, and water systems contain only few lakes. Therefore, the river

9 water is rich in organic matter. The $\mathrm{N}$ load to the rivers is at its highest in April - May, 10 diminishes rapidly towards summer months and peaks again slightly in late autumn.

11 In the Archipelago Sea the study site was at the Paimionlahti Bay, an estuary of the 12 river Paimionjoki (Figure 1A). The discharges of both freshwater and $\mathrm{N}$ compounds 13 to the bay are remarkably pulsed, with half of the $\mathrm{N}$ loading reaching the estuary in 14 April - May, and most of the other half late in the autumn. The flow diminishes 15 substantially for the summer months. In the Gulf of Finland, the study site was at the 16 Ahvenkoskenlahti Bay, which is a semi-enclosed estuary receiving loading from the 17 rivers Kymijoki and Taasianjoki (Figure 1A). The discharge, as well as the N loading, 18 fluctuate only modestly from season to season, and are usually highest in April - May. 19 In contrast to the rivers in the Bothnian Bay, the catchments of rivers Kymijoki and 20 Taasianjoki have low coverage of peatlands, but are significantly affected by 21 agriculture. The Paimionlahti Bay has a catchment with low lake content, while the 22 catchment of the Ahvenkoskenlahti Bay contains several lakes. 
1 Intact sediment cores were taken from three sampling sites in the river Temmesjoki

2 and four sites in the rivers Siikajoki, Pyhäjoki and Kalajoki in August 2004. The

3 sediment cores were incubated in a laboratory microcosm for three weeks. Samples

4 for the determination of denitrification were collected six times from each core during

5 the last two weeks.

7 Sediments were taken directly to transparent acrylic cores (ø $94 \mathrm{~mm}$, height $650 \mathrm{~mm}$ ).

8 The height of the intact sediments in the cores was $\leq 200 \mathrm{~mm}$. The sediment cores

9 were placed into laboratory microcosm equipped with continuous water flow [16].

10 The microcosm was situated in a dark, temperature controlled room at $15{ }^{\circ} \mathrm{C}$, similar

11 to the in situ temperatures in river waters during sampling $\left(13-20{ }^{\circ} \mathrm{C}\right.$, Table 1$)$. Water

12 was pumped from an 80-liter water reservoir over the cores by a peristaltic pump

13 (Ismatec, BVK-MS/CA8-6, Glattbrugg-Zürich, Switzerland) at the rate of $50 \mathrm{ml} \mathrm{h}^{-1}$.

14 Overlying water in the cores was gently stirred with a rotating magnet to prevent 15 stratification [16].

17 The water reservoir was vacuumed three times to remove $\mathrm{N}_{2}$ from the gas phase of the 18 water and flushed each time with gas mixture consisting of $\mathrm{Ar} / \mathrm{O}_{2}$ 80/20 (v/v) (AGA, 19 Finland) to improve the sensitivity of concentration analyses of $\mathrm{N}_{2}$ formed in 20 denitrification. Distilled water, amended with in situ concentrations of sulphate $(0.2$ $21 \mathrm{mM}$ ) and chloride $(0.5 \mathrm{mM})$ (added as $\mathrm{MgSO}_{4}$ and $\left.\mathrm{CaCl}_{2}\right)$, was used as inflow water.

22 The sediments were incubated at $30 \mu \mathrm{M}$ of ${ }^{15} \mathrm{NO}_{3}{ }^{-}\left(60\right.$ at \%). The fluxes of $\mathrm{NO}_{3}{ }^{-}$and 23 gases were measured from the difference between concentrations in the in- and 24 outflowing water. During the experiment the $\mathrm{NO}_{3}{ }^{-}$concentrations and the isotopic 25 composition $\left({ }^{15} \mathrm{~N} /{ }^{14} \mathrm{~N}\right)$ of the $\mathrm{NO}_{3}$ of the in- and outflowing water were determined 
1 three times in every week $\left(4^{\text {th }}, 5^{\text {th }}\right.$ and $6^{\text {th }}$ incubation days). Samples were stored at -20

$2{ }^{\circ} \mathrm{C}$ prior to analyses. $\mathrm{NO}_{3}{ }^{-}$and $\mathrm{SO}_{4}{ }^{2-}$ concentrations were measured with ion

3 chromatography (Dionex DX-130, Sunnyvale, CA, with an anion column A59-HC, 12

$4 \mathrm{mM} \mathrm{Na} \mathrm{CO}_{3}$ as an eluent). The $\mathrm{N}$ isotopic composition (at \%) of the $\mathrm{NO}_{3}^{-}$was

5 determined with R/CF-QMS (Reaction Continuous Flow Quadrupole Mass

6 Spectrometer) [17].

8 The fluxes of dissolved inorganic carbon (DIC) and dissolved gases $\mathrm{CH}_{4}, \mathrm{~N}_{2} \mathrm{O}$ and $\mathrm{N}_{2}$

9 were determined from the concentration differences between the in- and outflowing

10 water and by taking into account the flow rates and sediment surface area $\left(69 \mathrm{~cm}^{2}\right)$.

11 The water samples for DIC, $\mathrm{CH}_{4}$ and $\mathrm{N}_{2} \mathrm{O}$ were balanced for 1 day with an $\mathrm{Ar}$ 12 headspace, and then analyzed with a GC (Agilent 6890N, Agilent Technologies 13 Deutschland GmbH, Waldbronn, Germany) equipped with a peristaltic pump 14 (Minipuls 3, Gilson Inc., Middleton, WI, USA) and an autosampler (Gilson 15 autosampler 222XL, Gilson Inc., Middleton, WI, USA). The gas concentrations in the 16 original sample were calculated according to Henry's law (modified from McAuliffe 17 et al. 1971 [18]). The $\mathrm{N}_{2}$ samples were stored in vacuumed $12 \mathrm{ml}$ exetainers (Labco, 18 Co., UK) in concentrated salt solution $(\mathrm{NaCl})$. Concentration and isotopic 19 composition $\left({ }^{15} \mathrm{~N} /{ }^{14} \mathrm{~N}\right)$ of $\mathrm{N}_{2}$ were measured by a specifically configurated Gas 20 Chromatography Quadrupole Mass Spectrometer coupling (GC-QMS) (QP 2000, 21 Schimadzu Corp., [19]) The masses 28, 29 and 30 were measured and the peaks were 22 calibrated against normal air $\left(\begin{array}{llll}78 & \% & \mathrm{~N}_{2}\end{array}\right)$ for concentration measurements. The 23 contamination of samples by $\mathrm{N}_{2}$ in the laboratory atmosphere was prevented by 24 flushing the injection system and the sample loop of the GC with He flow before 
1 injection of the sample. The amount of $\mathrm{N}_{2}$ derived from denitrification was calculated

2 according to non-random distribution of the masses 28,29 and $30[20,21,22]$.

4 At the end of each incubation week the oxygen concentrations of overlying water 5 ( $1 \mathrm{~cm}$ above the sediment surface) were measured with an oxygen electrode

6 (Dissolved Oxygen Meter Oxi 330 with Dissolved oxygen Probe CellOx 325, WTW,

7 Weilheim, Germany), and $\mathrm{pH}(0.5 \mathrm{~cm}$ below the sediment surface $)$ was measured with 8 an electrode (Microprocessor $\mathrm{pH}$ meter $\mathrm{pH}$ 320, WTW, Germany, with Hamilton $\mathrm{pH}$ 9 electrode, Bonaduz, Switzerland).

11 Field measurements (Ahvenkoskenlahti Bay and Paimionlahti Bay)

12 Sediment was sampled either with a single or twin gravity corer, both having an inner 13 diameter of $80 \mathrm{~mm}$. Oxygen and $\mathrm{NO}_{3}{ }^{-}$concentrations in the overlying water were 14 measured about $2 \mathrm{~cm}$ above the sediment surface. Denitrification was measured using 15 the isotope pairing technique [15]. Three replicate sub-samples were taken in clear 16 plastic (acrylic) cores $(\varnothing 2.6 \mathrm{~cm}$, height $9 \mathrm{~cm})$ so that about half of the core was filled 17 with the sediment and half with the overlying water. Samples were enriched with $18 \mathrm{~K}^{15} \mathrm{NO}_{3}$ (98\% labelling, Cambridge Isotope Laboratories, MA, USA) to a final 19 concentration of $100 \mu \mathrm{M}$ of ${ }^{15} \mathrm{NO}_{3}{ }^{-}$in the water phase and incubated, with a magnetic 20 stirrer on the lid of the cores, at in situ temperature in darkness for 3 hours. The 21 biological activity was terminated with $\mathrm{ZnCl}_{2}$, and the samples were mixed. Sub22 samples of sediment-water slurry were sent in gas-tight $12 \mathrm{ml}$ vials (Exetainer, Labco, 23 UK) to the National Environmental Research Institute, Silkeborg, Denmark, for the 24 analysis of the $\mathrm{N}_{2}$ isotopic composition. 
2 In the laboratory experiments the total denitrification (Dtot) was calculated as a sum

3 of measured $\mathrm{N}_{2} \mathrm{O}$ and $\mathrm{N}_{2}$. Calculation of Dn (denitrification from coupled

4 nitrification-denitrification) based on the differences in the ${ }^{15} \mathrm{NO}_{3}$ - content in the

5 output water (i.e. overlying water) and in the output $\mathrm{N}_{2}\left(\right.$ and $\left.\mathrm{N}_{2} \mathrm{O}\right)$. Denitrification

6 based on the $\mathrm{NO}_{3}{ }^{-}$in the overlying water (Dw) was calculated as the remaining part of

7 the total denitrification.

9 In the field measurements, the share of Dw was calculated from the ratio of ${ }^{14} \mathrm{NO}_{3}{ }^{-}$

10 and ${ }^{15} \mathrm{NO}_{3}{ }^{-}$concentrations at the nitrate reducing zone and the Dtot [15]. Dn was then

11 calculated as the difference between Dtot and Dw.

13 Statistical analyses were done with SPSS statistical package (SPSS Inc. USA). The 14 normal distribution of the variables was tested with the Kolmogorov-Smirnov Test 15 and correlations of $\mathrm{N}_{2}$ effluxes to environmental variables with Spearman correlation 16 coefficients. The statistical significance of differences in denitrification and $\mathrm{N}_{2} \mathrm{O} / \mathrm{N}_{2}$ 17 between rivers were tested with Kruskall-Wallis' post hoc -test, suitable for non18 parametric data.

\section{Results}

21 Denitrification rates in the rivers in the Bothnian Bay

22 The total denitrification rates in the four river mouths varied between 330 and 905

$23 \mu \mathrm{mol} \mathrm{N} \mathrm{m} \mathrm{d}^{-1}$ (Figure 1A). Denitrification was mainly based on the nitrate diffusing

24 from the overlying water into the sediments (Dw), with only a minor share based on 25 the coupled nitrification-denitrification (Dn) (Figure 1A). The variation in 
1 denitrification rates within a site was high (e.g. the river Kalajoki, $906 \pm 590 \mu \mathrm{mol} \mathrm{N}$

$2 \mathrm{~m}^{-2} \mathrm{~d}^{-1}$, distance between replicate samples 500 - 1000 meters), and the denitrification

3 rates between the rivers did not differ statistically significantly. The denitrification

4 rate correlated positively $(0.876, \mathrm{p}=0.05)$ with the $\mathrm{CH}_{4}$ efflux, which varied from 0.02

5 to $2.3 \mathrm{mmol} \mathrm{m}^{-2} \mathrm{~d}^{-1}$ (Table 2 ), and with oxygen consumption $(0.550, \mathrm{p}=0.01)$, which

6 varied from 19 to $27 \mathrm{mmol} \mathrm{m}^{-2} \mathrm{~d}^{-1}$ (Table 2). It did not correlate with $\mathrm{pH}$ or with the

7 fluxes of $\mathrm{CO}_{2}$ or $\mathrm{NH}_{4}{ }^{+}$(Table 2). The $\mathrm{N}_{2} \mathrm{O}$ effluxes varied from 11 to $16 \mu \mathrm{mol} \mathrm{N} \mathrm{m} \mathrm{d}^{-2}$

$8{ }^{1}$ (Table 2). The percentage of $\mathrm{N}_{2} \mathrm{O}$ in the gaseous end products of denitrification did

9 not exceed $5 \%$. Differences in the $\mathrm{N}_{2} \mathrm{O}$ effluxes between the rivers were not 10 statistically significant.

12 Denitrification in the Bays in the Archipelago Sea and the Gulf of Finland

13 In Paimionlahti Bay, the denitrification rate varied tenfold within the estuary, from 90

$14 \mu \mathrm{mol} \mathrm{N} \mathrm{m} \mathrm{d}^{-1}$ in one station in the middle, to $910 \mu \mathrm{mol} \mathrm{N} \mathrm{m} \mathrm{d}^{-1}$ in the outer end of 15 the estuary. The bulk of denitrification was coupled to nitrification in the whole 16 estuary, and the proportion of denitrification that was dependent on the $\mathrm{NO}_{3}{ }^{-}$in the 17 water column (Dw) was at its highest in the middle estuary (Figure 1B), where the $18 \mathrm{NO}_{3}^{-}$concentration was highest. $\mathrm{Dw}$ was positively correlated with the $\mathrm{NO}_{3}^{-}$ 19 concentration $(0.917, \mathrm{p}=0.00)$ and negatively with the oxygen concentration $(-0.871$, $20 \mathrm{p}=0.000$ ). The rates of coupled nitrification-denitrification (Dn) and total 21 denitrification did not correlate with any of the environmental factors measured.

23 The denitrification rate in the Ahvenkoskenlahti Bay varied from 230 to $320 \mu \mathrm{mol} N$ $24 \mathrm{~m}^{-2} \mathrm{~d}^{-1}$. No clear gradient in the total denitrification could be seen within the basin, but 25 Dn increased from about $50 \%$ at the innermost station to about $80 \%$ towards the outer 
1 end of the basin (Figure 1C). Outside the basin, however, denitrification was lower

2 than in the basin itself, and the share of Dn was lower, reflecting the changes in the

3 sediment quality (higher water content and lower concentration of total carbon,

4 nitrogen and sulphur per sediment volume, data not shown).

6 The denitrification rates in the estuaries of the Gulf of Finland and Archipelago Sea

7 were in the same range in the rivers (Figure 1). The possible statistical differences

8 were not tested due to the differences in the methodology.

104 Discussion

11 Denitrification rates

12 Denitrification rates reported from the rivers range up to $18000 \mu \mathrm{mol} \mathrm{N} \mathrm{m}{ }^{-2} \mathrm{~d}^{-1}$ [23].

13 The studies made in northern latitudes are few, but Garcia-Ruiz et al. [24] reported 14 rates of $0-13800 \mu \mathrm{mol} \mathrm{N} \mathrm{m}{ }^{-2} \mathrm{~d}^{1}$, from the Swale-Ouse river system in UK. In this 15 study, the denitrification rates in the rivers were lower $\left(330-910 \mu \mathrm{mol} \mathrm{N} \mathrm{m} \mathrm{d}^{-1}\right)$ than 16 those measured from other river ecosystems, but higher than the values measured in 17 the open sea area of the Bothnian Bay $\left(120-160 \mu \mathrm{mol} \mathrm{N} \mathrm{m} \mathrm{N}^{-2}\right)$ [10]. They fall into 18 same range with the values measured from the open Gulf of Bothnia $(0-940 \mu \mathrm{mol} N$ $\left.19 \mathrm{~m}^{-2} \mathrm{~d}^{-1}\right)$ [10]. In those studies, denitrification was measured using the acetylene 20 blockage method, now known to have some serious flaws (inhibition of nitrification 21 [25], reversal of blockage by sulphide [26], incomplete blockage by acetylene [27], 22 scavenging of intermediate NO [28]). Therefore, the earlier denitrification estimates 23 from the open Gulf of Bothnia [10] may be too low. If that is the case, the rates 24 measured in the river estuaries are, in fact, lower than those measured in the open sea. 25 In the Bothnian Sea, denitrification rate, measured using the isotope pairing technique 
1 [15] varied between 250 and $300 \mu \mathrm{mol} \mathrm{N} \mathrm{m} \mathrm{d}^{-1}$ [9], which is lower than the rates

2 measured in the river sediments in this study, and also lower than the rates measured

3 in the Paimionlahti Bay $\left(90-910 \mu \mathrm{mol} \mathrm{N} \mathrm{m} \mathrm{d}^{-1}\right.$, average $\left.460 \mu \mathrm{mol} \mathrm{N} \mathrm{m} \mathrm{d}^{-1}\right)$, southern

4 Gulf of Bothnia.

6 In the Gulf of Finland, denitrification measurements have been done using the isotope 7 pairing technique since the mid-90's. Gran and Pitkänen [14] found a gradient in the 8 denitrification rates from the eastern Gulf of Finland, inner Neva estuary, towards the 9 open Gulf. The denitrification rates were lowest $\left(<10 \mu \mathrm{mol} \mathrm{N} \mathrm{m}{ }^{-2} \mathrm{~d}^{-1}\right)$ in the inner 10 Neva estuary, higher in the outer estuary and the highest, up to $1260 \mu \mathrm{mol} \mathrm{N} \mathrm{m} \mathrm{d}^{-1}$, in 11 the open Gulf of Finland. Tuominen et al. [9] measured the highest denitrification 12 rates of $150-650 \mu \mathrm{mol} \mathrm{N} \mathrm{m} \mathrm{N}^{-2} \mathrm{~d}^{-1}$ from open sea area of the Gulf of Finland, with lower 13 rates in the eastern and western ends of the Gulf $\left(100-400 \mu \mathrm{mol} \mathrm{N} \mathrm{m} \mathrm{N}^{-2}\right)$. Thus, the 14 denitrification rates in the Ahvenkoskenlahti Bay (Gulf of Finland) $(230-320 \mu \mathrm{mol} \mathrm{N}$ $15 \mathrm{~m}^{-2} \mathrm{~d}^{-1}$, average $280 \mu \mathrm{mol} \mathrm{N} \mathrm{m} \mathrm{N}^{-2}$ ) are in the lower end reported for the Gulf. 16 However, there can be some overestimation in the rates reported for the open Gulf of 17 Finland, resulting from the potential effect of anammox in the estimates, whereas no 18 anammox was detected in the Ahvenkoskenlahti Bay. The denitrification rates in the 19 Ahvenkoskenlahti Bay were much higher than the rates outside the bay, towards the 20 open Gulf of Finland (Figure 1C). The stations at the estuary were located on 21 accumulation bottoms, with high carbon and nitrogen content per sediment volume, 22 whereas the stations on the transportation /transient accumulation bottoms outside the 23 estuary had very low dry matter and low carbon and nitrogen content per sediment 24 volume. In the Paimionlahti Bay, the inner estuary rates were slightly (but 25 significantly, $\mathrm{p}=0.01$ ) lower than those immediately outside the estuary (Figure 1B). 
1 As the highly variable denitrification rate $\left(260-620 \mu \mathrm{mol} \mathrm{N} \mathrm{m} \mathrm{N}^{-2}\right.$, with a single

2 station showing a rate of $90 \mu \mathrm{mol} \mathrm{N} \mathrm{m}^{-2} \mathrm{~d}^{-1}$ ) did not correlate with any of the

3 environmental factors measured (depth, temperature, salinity, oxygen and

4 nitrite/nitrate concentration, total carbon, nitrogen and loss on ignition in the

5 sediment) likewise showing high variation, it is unclear why the rates outside the

6 estuary basin were higher $\left(720-910 \mu \mathrm{mol} \mathrm{N} \mathrm{m} \mathrm{m}^{-2} \mathrm{~d}^{-1}\right)$.

8 Although the total denitrification rates fall into the same range in the laboratory

9 experiments and in the field measurements, the ratio of Dw/Dn was remarkably

10 different. In the laboratory experiments, the share of Dn was always less than $10 \%$,

11 whereas in the field measurements the share was $50-85 \%$ in Ahvenkoskenlahti and 12 65-95\% in Paimionlahti. Similar results - small share of Dn - have been reported 13 earlier from flow-though systems as well [29,23]. In the laboratory experiments, the 14 sediment surface is continuously provided with $\mathrm{NO}_{3}^{-}$, mimicking the natural 15 conditions in river ecosystems. Dw correlates with the $\mathrm{NO}_{3}{ }^{-}$concentration, and the 16 high $\mathrm{NO}_{3}{ }^{-}$concentrations in river waters (Table 1) are likely to sustain high Dw in the 17 river sediments. The $\mathrm{NO}_{3}{ }^{-}$concentrations were much higher in the rivers than in the 18 two estuaries (Table 1), and probably explain the lower share of Dn in the river 19 sediments. Low share of Dn has been reported from river and estuary systems using 20 the isotope pairing technique, too. [e.g. 30,31].In river sediments $\mathrm{NO}_{3}{ }^{-}$is easily 21 available in the denitrification zone due to more efficient penetration and thus the 22 importance of nitrification as $\mathrm{NO}_{3}{ }^{-}$source is diminished. Another factor affecting the 23 share of Dn is the oxygen concentration in the overlying water of the sediments. Low 24 oxygen concentration lowers the oxygen penetration depth, thereby enhancing Dw by 25 shortening the distance $\mathrm{NO}_{3}{ }^{-}$needs to diffuse into the denitrifying zone in the 
1 sediment. Oxygen deficiency also lowers nitrification rate, and thereby Dn rate [32].

2 In the laboratory experiments the oxygen demand was high, but no anoxia developed

3 due to continuous feeding of the system with oxic water. Also in the field

4 measurements oxygen was not limiting nitrification and Dn, as the rates were high

5 and did not correlate with oxygen concentration.

6

$7 \quad \mathrm{~N}_{2} \mathrm{O}$ production in denitrification

8 The $\mathrm{N}_{2} \mathrm{O}$ effluxes measured in the river sediments (manipulation experiments) were

9 lower than the rates reported for rivers in the literature [33,34,35]. In the river Swale-

10 Ouse, NE England, the lowest effluxes, measured at the highest upstream sites [36],

11 were more than ten times the effluxes measured in this study. The $\mathrm{N}_{2} \mathrm{O}$ effluxes have

12 not been measured from the rivers of the northern Baltic Sea before. In shallow

13 profundal sediments of freshwater lake of the same latitude, the effluxes in aerobic

14 conditions were of the same magnitude (up to $17 \mu \mathrm{mol} \mathrm{N}_{2} \mathrm{O}-\mathrm{N} \mathrm{m}^{-2} \mathrm{~d}^{-1}$ ) [37] as

15 measured from the rivers in this study. Seitzinger et al. [8] reported that in eutrophic

16 water ecosystems, up to $5 \%$ of the gases produced in denitrification are released as

$17 \mathrm{~N}_{2} \mathrm{O}$. Of the rivers studied in the manipulation experiment, none showed such a high

18 ratio. The $\mathrm{N}_{2} \mathrm{O}$ production rates measured were low, and therefore the $\mathrm{N}$ removal by

19 denitrification did not, so far, have a significant climatic impact. Increasing $\mathrm{NO}_{3}{ }^{-}$

20 concentrations in the river water would, however, probably enhance $\mathrm{N}_{2} \mathrm{O}$ over $\mathrm{N}_{2}$.

21 Ratios as high as $80 \%$ have been measured from very eutrophic rivers in NE-England

22 [38] and very high $\mathrm{N}_{2} \mathrm{O}$ concentrations exist in estuaries around the world [39,5], also

23 in the southern Baltic Sea [40]. 
1 Until recently, denitrification was seen as the only process removing fixed nitrogen

2 from the water ecosystem. However, a decade ago, another nitrogen removing

3 process, anammox (anaerobic ammonium oxidation), was discovered in wastewater

4 treatment plants [41,42], and later also in marine sediments $[43,44,45,46]$. In a recent

5 study, anammox was found in a coastal station of the northern Gulf of Finland,

6 too(Hietanen S. and Kuparinen J. Seasonal and short-term variation in denitrification

7 and anammox at a coastal station on the Gulf of Finland, Baltic Sea. Submitted). The

8 discovery of the anammox process in these sediments challenges the previous

9 measurements made in the area, as the coexistence of anammox and denitrification

10 compromises the central assumptions behind the method used in denitrification

11 measurements, and causes overestimates in the $\mathrm{N}_{2}$ production. Therefore, the true $\mathrm{N}_{2}$

12 production rates can not be reliably calculated without knowing the share of anammox

13 in the total $\mathrm{N}_{2}$ production. In the coastal Gulf of Finland, anammox contributed 10-

$1415 \%$ to the total $\mathrm{N}_{2}$ production, with the effect that the $\mathrm{N}_{2}$ production was

15 overestimated by $80-150 \%$ (Hietanen S. and Kuparinen J. Seasonal and short-term

16 variation in denitrification and anammox at a coastal station on the Gulf of Finland,

17 Baltic Sea. Submitted). It has been studied also the Ahvenkoskenlahti Bay, and found

18 to be negligible $(<1 \%$ ) (Hietanen, S. Anammox in the sediments of the Gulf of

19 Finland. Submitted). Thus, there is no bias in the $\mathrm{N}_{2}$ production rates presented here

20 for that estuary. Anammox was not measured at the other field measurement area, the

21 Paimionlahti Bay, where much higher denitrification rates were found, nor in the river

22 sediments used in the laboratory experiments. Therefore, it is possible that the

23 denitrification rates presented here for these areas are overestimates. Anammox has so

24 far been measured only in two different river ecosystems, the temperate Thames

25 estuary [45] and a subtropical Logan and Albert river system in Australia [47]. In both 
1 of these locations, the highest contribution of anammox to the overall $\mathrm{N}_{2}$ production

$2(8-9 \%)$, as well as the highest rates, were measured upstream, with decreasing rates

3 towards the river mouth and open sea, where anammox was found to be negligible. In

4 addition, the relative contribution of anammox to the overall nitrogen reduction has

5 often been found to be minor in coastal environments, and to increase with depth, as

6 the rate of denitrification decreases $[43,48,49]$. Based on these published findings and

7 those measured from Ahvenkoskenlahti Bay and the coastal station at the Gulf of

8 Finland, we have assumed that in the Paimionlahti Bay and the river sediments, the

9 anammox activity is negligible, and our denitrification estimates therefore valid.

11 Importance of nitrogen removal by denitrification

12 We evaluated the efficiency of the nitrogen removal in the studied estuaries. In the 13 laboratory experiments, the calculations of $\mathrm{N}$ removal are based on Dw, due to the 14 small share of $\mathrm{Dn}$. The $\mathrm{NO}_{3}{ }^{-}$removal by denitrification was calculated as a ratio of 15 output labelled gaseous nitrogen species to the input of labelled $\mathrm{NO}_{3}^{-}$. Dw accounted 16 for $17-22 \%$ total $\mathrm{NO}_{3}{ }^{-}$removal. The overall $\mathrm{NO}_{3}{ }^{-}$removal, which includes DNRA 17 and assimilation in addition to denitrification, was 21-27\%. According to these 18 results, denitrification was always the most important process removing nitrate, if the 19 assumption of negligible anammox is correct. When estimating the role of 20 denitrification in reducing the total nitrogen load in situ, one has to bear in mind that 21 only a share of total nitrogen is in the form of nitrate in the river waters (Table 1). No 22 information exists yet about the seasonal variation of denitrification in these 23 ecosystems, nor does about the possible differences in the rates between accumulation 24 and transportation bottoms. Stockenberg and Johnstone [23] have suggested that the 25 denitrification rate on transportation and erosion areas is only $30 \%$ of that on the 
1 accumulation areas. The studied sediments were collected from accumulation bottoms

2 only, and the share of accumulation bottoms has not been mapped in these rivers.

3 Therefore, the estimate given only applies for the environmental conditions prevailing

4 during the experiment.

6 The two estuaries studied differed greatly from each other in their capacity to remove 7 nitrogen entering the bay. In Ahvenkoskenlahti Bay in August 2004, assuming that 8 the denitrification rate was similar throughout the basin, the average rate of $280 \mu \mathrm{mol}$ $9 \mathrm{~N} \mathrm{~m}^{-2} \mathrm{~d}^{-1}$ (Dw $86 \mu \mathrm{mol} \mathrm{N} \mathrm{m}{ }^{-2} \mathrm{~d}^{-1}$ ) removed $1.7 \%$ of $\mathrm{NO}_{3}^{-}$loading (by Dw) and $3.6 \%$ 10 of the total $\mathrm{N}$ loading (by Dtot) reaching the bay. The share of accumulation bottom in 11 the study area is $58 \%$ (Heikki Pitkänen, SYKE, unpubl.). Using the lower rates for 12 the transportation and erosion areas [23] gives only $1.2 \%$ reduction to the nitrate and $131 \%$ reduction to the total nitrogen loading in August 2004. In Paimionlahti Bay the 14 average denitrification rate of $460 \mu \mathrm{mol} \mathrm{N} \mathrm{m} \mathrm{N}^{-1}$ (Dw $70 \mu \mathrm{mol} \mathrm{N} \mathrm{m} \mathrm{N}^{-1}$ ) was high 15 enough to remove all of the nitrogen loading reaching the bay in September 2003. The 16 year 2003 was exceptionally dry, so the nitrogen removal was calculated also using 17 the loading data of more typical conditions in September 2004. If the denitrification 18 rate was similar in $2004,4.5 \%$ of nitrate loading and $19 \%$ of total nitrogen loading 19 were removed from the water in the estuary in 2004. The amount of accumulation 20 areas has not been mapped in the Paimionlahti Bay, and the given value is likely to be 21 an overestimate.

23 The residence time has been indicated as having a major effect in the estuarine 24 retention capacity in several different estuaries [30,50,51,52,53]. In Ahvenkoskenlahti 25 Bay, the discharge is high year round, and the estimated residence time fluctuates 
1 between 10 and 14 days (average 12 days). In the larger and deeper Paimionlahti Bay,

2 the flow is 20 times lower and more pulsed, and the calculated residence time varies

3 from 2 to 19 years (average 7 years). Clearly, more nitrogen is removed as it stays

4 longer in the estuary, and, therefore, Paimionlahti Bay is more efficient in removing 5 nitrogen than Ahvenkoskenlahti Bay.

6

$7 \quad$ Estuaries and river mouths as $N$ filters in northern Baltic

8 In 1988, Seitzinger [8] introduced a "rule of thumb" of $40-50 \%$ removal of $\mathrm{N}$ by

9 denitrification in estuaries, indicating them as important filters for the $\mathrm{N}$ loading 10 transported towards the sea, and therefore having a considerable role in slowing down 11 eutrophication of seas. Since then, various studies have either supported [e.g. 12] or 12 opposed $[51,53,54,55,56]$ this claim. Only few studies have been made in the Baltic

13 Sea area. A lowland stream entering the Kattegat was found to remove less than $1 \%$ 14 of the annual loading, although during low discharge in summer, the removal was 15 temporarily up to $60 \%$ of the loading [30]. Similarly, a small, shallow estuary opening 16 to the Kattegat denitrified only $2 \%$ of the annual loading [50]. In the Swedish east 17 coast, a coastal embayment was found to remove $5-11 \%$ of wastewater $\mathrm{N}$ input, with 18 denitrification being the most important mechanism for removal [11]. A study of 19 several rivers entering the Gulf of Bothnia revealed them to be ineffective sinks of $\mathrm{N}$ 20 [13]. All of these studies, as well as the results presented here, confirm the pattern of 21 increasing efficiency with decreasing discharge, suggested by Nixon (1996). In 22 conclusion, according to our results, the sediments of the fast flowing rivers and the 23 estuary areas with short residence times of both the Gulf of Bothnia and the Gulf of 24 Finland are inefficient filters of $\mathrm{N}$ load. This emphasizes the role of reduction of 
1 anthropogenic $\mathrm{N}$ loading to the high latitude rivers and estuaries in order to avoid

2 further eutrophication of susceptible sea areas.

3

4 References and notes

5 Acknowledgements

6 We thank FM Mika Visuri form Finnish Environmental Centre for his valuable help

7 in sediment sampling and Mr. Bernd Apelt for his assistance in laboratory work. Paula

8 Väänänen (SYKE) and Jaana Rintala (North Osthrobothnia Regional Environmental

9 Centre) are acknowledged for the maps and Antti Räike (SYKE) for the loading data

10 of the estuaries. This study was funded by the Academy of Finland's BIREME

11 programme for the COASTGAS (Academy of Finland decision number 202429) and

12 the SEGUE consortium, project SEGUE-N (Academy of Finland decision number

13 202444). H.S got funding also from the Graduate School of Environmental Science

14 and Technology (EnSTe).

15

16 References

17 1. HELCOM, 2003. Helsinki Commission, Baltic Marine Environment Protection

18 Commission. The Baltic Marine Environment 1999-2002. Summary. Baltic Sea $19 \quad$ Environment Proceeding No. 87.

20 2. Kronholm, M., Albertsson, J. and Laine, A. 2005. Bothnian Bay Life. Bothnian Bay

21 Protection Plan. Länsstyrelsen i Norrbottens län raportserie 1/2005.

22 3. Pitkänen, H., Lehtoranta, J. and Räike, A. 2001. Internal nutrient fluxes counteract

23 decreases in external load: The case of the estuarial eastern Gulf of Finland, Baltic

24 Sea. Ambio 30, 195-201. 
1 4. Kiirikki, M., Rantanen, P., Varjopuro, R., Leppänen, A., Hiltunen, M., Pitkänen, H., Ekholm, P., Moukhametsina, E., Inkala, A., Kuosa, H. and Sarkkula, J. 2003. Cost effective water protection in the Gulf of Finland. Focus on St. Petersburg. The Finnish Environment 632. Edita Publishing Ltd, Vantaa. 55 pp.

5. Seitzinger, S.P., Kroeze, C. and Styles, R.V. 2000. Global distribution of $\mathrm{N}_{2} \mathrm{O}$ emissions and anthropogenic effects. Chemosphere - Global Change Science 2, 269-279.

6. Kroeze, C. and Seitzinger, S.B. 1998. Nitrogen inputs to rivers, estuaries and continental shelves and related to nitrous oxide emissions in 1990 and 2050. Nutr. Cycl. Agroecosys. 52, 195-212.

7. Knowles, R. 1981. Denitrification. In: Clark, F.E. and T. Rosswall (Eds.), Terrestrial Nitrogen Cycles, Processes, Ecosystem Strategies and Management Impacts. Ecol. Bull. No33, Swedish Natural Science Research Council. pp. 315866.

8. Seitzinger, S. P. 1988. Denitrification in freshwater and coastal marine ecosystems: Ecological and geochemical significance. Limnol. Oceanogr. 33: 702-724.

9. Tuominen, L., Heinänen, A., Kuparinen, J. and Nielsen, L.P. 1998. Spatial and temporal variability of denitrification in the sediments of the northern Baltic Proper. Mar. Ecol. Prog. Ser. 172, 13-24.

10. Stockenberg, A. and Johnstone, R.W. 1997. Benthic denitrification in the Gulf of Bothnia. Estuar. Coastal Shelf Sci. 45, 835-843.

11. Savage, C., Leavitt, P.R. and Elmgren, R. 2004. Distribution and retention of effluent nitrogen in surface sediments of a coastal bay. Limnol. Oceanogr. 49, $1503-1551$ 
1 12. Ogilvie, B., Nedwell, D.B., Harrison, R.M., Robinson, A. and Saqe, A.1997. High

2 nitrate, muddy estuaries as nitrogen sinks: The nitrogen budget of the River Colne estuary (United Kingdom). Mar. Ecol. Prog. Ser. 150, 217- 228.

4 13. Humborg, C., Danielsson, Å., Sjöberg, B. and Green, M. 2003. Nutrient land-sea 5 dynamics in oligotrophic and pristine estuaries of the Gulf of Bothnia, Baltic Sea. Estuar. Coastal Shelf Sci. 56, 781-793.

14. Gran, V. and Pitkänen, H. 1999. Denitrification in estuarine sediments in the eastern Gulf of Finland, Baltic Sea. Hydrobiologia 393, 107-115.

15. Nielsen, L.P. 1992. Denitrification in sediment determined from nitrogen isotope pairing. FEMS Microbiol. Ecol. 86, 357-362.

11 16. Liikanen, A., Tanskanen, H., Murtoniemi, T. and Martikainen, P.J. 2002. A laboratory microcosm for simultaneous gas and nutrient flux measurements in

17. Russow, R. 1999. Determination of $15 \mathrm{~N}$ in $15 \mathrm{~N}$-enriched nitrite and nitrate in aqueous samples by reaction continuous-flow quadropole mass spectrometry. Rapid Commun. Mass Sp. 13, 1334-1338.

18. McAuliffe, C. 1971. GC determination of solutes by multiple phase equilibration. Chemtech. 1, 46-51.

19. Russow, R., Sich, I. and Foerstel, H. 1997. A GC-QMS aided incubation system for trace gas studies in soils using stable isotopes. In: Nuclear and Related Techniques in Soil/Plant Studies on Sustainable Agriculture and Environmental Preservation, IAEA-SM-334/1, Vienna, 1995, 63-72.

20. Hauck, R.D., Melsted, S.W. and Yanlwitch, P.E. 1958. Use of N-isotope distribution in nitrogen gas in the study of denitrification. Soil Sci. 86, 287-291. 
1 21. Siegel, R.L., Hauck, R.D. and Kurtz, L.T. 1982. Determination of ${ }^{30} \mathrm{~N}_{2}$ and application to measurement of $\mathrm{N}_{2}$ evolution during denitrification. Soil Sci. Soc. 46, 68-74.

22. Russow, R., Stevens, R.J. and Laughlin, R.J. 1996. Accuracy and Precision for measurements of the mass ratio 30/28 in dinitrogen from air samples and its application to the investigation of $\mathrm{N}$ losses from soil by denitrification. Isot. Environ. Healt. S. 32, 289-297.

23. Steingruber, S.M., Friedrich, J., Gächter, R. and Wehrli, B. 2001. Measurement of denitrification in sediments with the ${ }^{15} \mathrm{~N}$ isotope pairing technique. Appl. Environ. Microb. 67, 3771-3778.

24. Garcia-Ruíz, R., Pattinson, S.N. and Whitton, P.A.1998. Denitrification in sediments of the fresh water tidal Yorkshire Ouse. Sci. Total Environ. 210/211, 321-327.

25. Seitzinger, S.P., Nielsen, L.P., Caffrey J. and Christensen, P.B. 1993.

Denitrification measurements in aquatic sediments: a comparison of three methods. Biogeochemistry 23, 147-167.

26. Sørensen, J., Rasmussen, L.K. and Koike, I.1987. Micromolar sulphide concentrations alleviate acetylene blockage of nitrous oxide reduction by denitrifying Pseudomonas fluorescence. Can. J. Microbiol. 33, 1001-1005.

27. Christensen, P.B., Nielsen, L.P., Revsbech, N.P. \& Sørensen, J. 1989. Microzonation of denitrification activity in stream sediments as studied with a combined oxygen and nitrous oxide microsensor. Appl. Environ. Microb. 55, 1234-1241. 
1 28. Bollmann A. and Conrad R.1997. Acetylene blockage technique leads to underestimation of denitrification rates in oxic soils due to scavenging of intermediate nitric oxide. Soil Biol. Biochem. 29 1067-1075

29. Rysgaard, S., Risgaard-Petersen, N., Nielsen, L.P. and Revsbech, N.P.1993.

30. Pind, A., Risgaard-Petersen, N. and Revsbech, N.P.1997. Denitrification and microphytobenthic $\mathrm{NO}_{3}{ }^{-}$consumption in a Danish lowland stream: diurnal and seasonal variation. Aquat. Microb. Ecol. 12, 275-284.

31. Rysgaard, S., Christensen, P.B. and Nielsen, L.P. 1995. Seasonal variation in nitrification and denitrification in estuarine sediment colonized by benthic microalgae and bioturbating fauna. Mar. Ecol. Prog. Ser. 126, 111-121.

32. Jensen, K., Sloth, N.P., Risgaard-Petersen, N., Rysgaard, S. and Revsbech, N.P. 1994. Estimation of nitrification and denitrification from microprofiles of oxygen and nitrate in model sediment systems. Appl. Environ. Microb. 60: 2094-2100.

33. de Bie, M.J.M., Middelburg, J.J., Starink, M. and Laanbroek, H.J. 2002. Factors controlling nitrous oxide at the microbial community and estuarine scale. Mar. Ecol. Prog. Ser. 240, 1-9.

34. Elkins, J.W., Wofsy, S.C., McElroy, M.B., Kolb, C.E. and Kaplan, W.A.1978. Aquatic sources and sinks for nitrous oxide. Nature 275, 602-606.

35. Laursen, A.E. and Seitzinger, S.P. 2004. Diurnal patterns of denitrification, oxygen consumption and nitrous oxide production in rivers measured at the whole-reach scale. Freshwater Biol. 49, 1448-1458. 
1 36. García-Ruiz, R., Pattinson, S.N. and Whitton, B.A. 1999. Nitrous oxide production in the river Swale-Ouse, North-East England. Wat. Res. 33, 12311237.

37. Liikanen, A., Flöjt, L. and Martikainen, P.J. 2002. Gas dynamic in eutrophic lake sediments affected by oxygen nitrate and sulphate. J. Environ. Qual. 31, 338-349.

38. Garcìa-Ruiz, R., Pattinson, S.N. and Whitton, B.A. 1998b Kinetic Parameters of denitrification in a river continuum. Appl. Environ. Microb. 64, 2533-2538.

39. McMahon, P.B. and Dennehy, K.F. 1999. $\mathrm{N}_{2} \mathrm{O}$ emissions from a nitrogenenriched river. Environ. Sci. Tech. 33, 21-25.

40. Bange, H.W., Rapsomanikis, S. and Andreae, M.O.1996. Nitrous oxide in coastal waters. Global Biogeochem. Cy. 10, 197-207.

41. Mulder, A., Van de Graaf, A.A., Robertson, L.A. and Kuenen, J.G. 1995. Anaerobic ammonium oxidation discovered in a denitrifying fluidized bed reactor. FEMS Microbiol. Ecol. 16, 177-184.

42. Van de Graaf, A.A., Mulder, A., De Bruijn, P., Jetten, M.S.M., Robertson, L.A. and Kuenen, J.G. 1995. Anaerobic oxidation of ammonium is a biologically mediated process. Appl. Environ. Microb. 61, 1246-1251.

43. Thamdrup, B. and Dalsgaard, T. 2002. Production of $\mathrm{N}_{2}$ through anaerobic ammonium oxidation coupled to nitrate reduction in marine sediments. Appl. Environ. Microb. 68:1312-1318.

44. Dalsgaard, T. and Thamdrup, B. 2002. Factors controlling anaerobic ammonium oxidation with nitrite in marine sediments. Appl. Environ. Microb. 68, 3802-2808.

45. Trimmer, M., Nicholls, J.C. and Deflandre, B. 2003. Anaerobic ammonium oxidation measured in sediments along the Thames estuary. Appl. Environ. Microb. 69, 6447-6454. 
1 46. Arrigo, K.R. 2005. Marine microorganisms and global nutrient cycles. Nature 437, 349-355.

47. Meyer, R.L., Risgaard-Petersen, N. and Allen, D.E. 2005. Correlation between anammox activity and microscale distribution of nitrite in subtropical mangrove sediment. Appl. Environ. Microb. 71, 6142-6149.

48. Risgaard-Petersen, N., Meyer, R.L., Schmid, M., Jetten, M.S.M., Enrich-Prast, A., Rysgaard, S.and Revsbech, N.P. 2004. Anaerobic ammonium oxidation in an estuarine sediment. Aquat. Microb. Ecol. 36, 293-304.

49. Engström, P., Dalsgaard, T., Hulth, S. and Aller, R.C. 2005. Anaerobic ammonium oxidation by nitrte (anammox): Implications for $\mathrm{N}_{2}$ production in coastal marine sediments. Geochim. Cosmochim. Acta 69, 2057-2065.

50. Nielsen, K., Nielsen, L.P. and Rasmussen. P.1995. Estuarine nitrogen retention independently estimated by the denitrification rate and mass balance methods: a study of Norsminde Fjord, Denmark. Mar. Ecol. Prog. Ser. 119, 275-283.

51. Kelly, R. 1997. Nitrogen flow and the interaction of Boston Harbor with Massachusetts Bay. Estuaries 20, 365-380.

52. Nedwell, D.B. and Trimmer, M. 1996. Nitrogen fluxes through the upper estuary of the Great Ouse, England: The role of the bottom sediments. Mar. Ecol. Prog. Ser. 142, 273-286.

53. Nixon, S.W., Ammerman, J.W., Atkinson, L.P., Berounsky, V.M., Billen, G., Boicourt, W.C., Boynton, W.R., Church, T.M. et al.. 1996. The fate of nitrogen and phosphorus at the land-sea margin of the North Atlantic Ocean. Biogeochemistry 35,141-180. 
1 54. Nowicki, B.L., Requintina, E., VanKeuren, D. and Kelly, J.R.1997. Nitrogen

2 losses through sediment denitrification in Boston Harbor and Massachusetts Bay. 3 Estuaries 20, 626-639.

4 55. Trimmer, M., Nedwell, D.B., Sivyer, D.B. and Malcolm, S.J. 1998. Nitrogen

5 fluxes through the lower estuary of the river Great Ouse, England: the role of the 6 bottom sediments. Mar. Ecol. Prog. Ser. 163, 109-124.

7 56. Cabrita, M.T. and Brotas, V. 2000. Seasonal variation in denitrification and 8 dissolved nitrogen fluxes in intertidal sediments of the Tagus estuary, Portugal. 9 Mar. Ecol. Prog. Ser. 202, 51-65. 


\section{$1 \quad$ Illustrations and tables}

2 Table 1. Description of the study areas. ND not determined. DIN dissolved inorganic nitrogen.

\begin{tabular}{|c|c|c|c|c|c|c|c|c|c|c|c|c|}
\hline & & & & & & Annual & & During & npling & & & \\
\hline & $\begin{array}{l}\text { Drainage } \\
\text { basin } \mathrm{km}^{2}\end{array}$ & $\begin{array}{l}\text { Cultivated } \\
\text { field \% }\end{array}$ & $\begin{array}{l}\text { Peatlands } \\
\%\end{array}$ & $\begin{array}{l}\text { Forests } \\
\%\end{array}$ & $\begin{array}{l}\text { Lakes } \\
\%\end{array}$ & $\begin{array}{l}\text { Mean flow } \\
\mathrm{m}^{3} \mathrm{~s}^{-1}\end{array}$ & $\begin{array}{l}\text { N load } \\
\text { tons }\end{array}$ & $\begin{array}{l}\mathrm{NO}_{3}-\mathrm{N} \\
\mu \mathrm{M}\end{array}$ & $\begin{array}{l}\mathrm{DIN} / \mathbf{N}_{\text {tot }} \\
\%\end{array}$ & $\begin{array}{l}\mathrm{NO}_{3} / \mathrm{DIN} \\
\%\end{array}$ & $\begin{array}{l}\text { Temp } \\
{ }^{\circ} \mathrm{C}\end{array}$ & $\begin{array}{l}\mathbf{O}_{2} \\
\mu \mathrm{M}\end{array}$ \\
\hline $\begin{array}{l}\text { River Temmesjoki } \\
\text { Estuary }\end{array}$ & 1184 & 15 & 2 & 82 & 0.5 & 11 & 520 & 80 & 48 & 88 & $14-18$ & ND \\
\hline $\begin{array}{l}\text { River Siikajoki } \\
\text { Estuary }\end{array}$ & 4318 & 8 & 3 & 87 & 2 & 60 & 1700 & 20 & 26 & 92 & $15-20$ & ND \\
\hline $\begin{array}{l}\text { River Pyhajoki } \\
\text { Estuary }\end{array}$ & 3724 & 10 & 0 & 85 & 5 & 40 & 1620 & 25 & 23 & 95 & $15-19$ & ND \\
\hline $\begin{array}{l}\text { River Kalajoki } \\
\text { Estuary }\end{array}$ & 4247 & 16 & 0 & 82 & 2 & 50 & 4000 & 70 & 44 & 98 & $13-20$ & ND \\
\hline $\begin{array}{l}\text { Paimionlahti } \\
\text { Bay }\end{array}$ & 1088 & 42 & 4 & 45 & 2.7 & 7 & 950 & $2-24$ & 100 & 99 & $8-11$ & $65-250$ \\
\hline $\begin{array}{l}\text { Ahvenkoskenlahti } \\
\text { Bay }\end{array}$ & 37158 & 9 & 11 & 56 & 19 & 175 & 3540 & $3-10$ & 29 & 88 & $8-18$ & $170-280$ \\
\hline
\end{tabular}


1 Table 2. Oxygen demand ( $\left.\mathrm{mmol} \mathrm{m}^{-2} \mathrm{~d}^{-1}\right)$ and fluxes of nitrous oxide $\left(\mu \mathrm{mol} \mathrm{N} \mathrm{m} \mathrm{m}^{-1}\right)$, methane, carbon dioxide and inorganic nitrogen species 2 from sediment to the water $\left(\mathrm{mmol} \mathrm{m}^{-2} \mathrm{~d}^{-1}\right)$ and $\mathrm{pH}$ in the manipulation experiments (average and standard deviation). DIC dissolved inorganic 3 carbon. $\mathrm{N}$ number of replicates.

\begin{tabular}{lcccccccc}
\hline & $\mathbf{N}$ & $\begin{array}{c}\mathbf{O}_{\mathbf{2}} \\
\text { demand }\end{array}$ & $\mathbf{N}_{\mathbf{2}} \mathbf{O}-\mathbf{N}$ & $\mathbf{C H}_{\mathbf{4}}-\mathbf{C}$ & $\mathbf{D I C}$ & $\mathbf{N O}_{\mathbf{3}}-\mathbf{N}$ & $\mathbf{N H}-\mathbf{N}$ & $\mathbf{p H}$ \\
\hline $\begin{array}{l}\text { River Temmesjoki } \\
\begin{array}{l}\text { Estuary } \\
\text { River Siikajoki }\end{array}\end{array}$ & $\mathbf{3}$ & $19 \pm 2.0$ & $15.1 \pm 3.4$ & $0.8 \pm 0.7$ & $37 \pm 4.5$ & $-0.3 \pm 0.2$ & $3.7 \pm 1.5$ & $5.4 \pm 0.1$ \\
$\begin{array}{l}\text { Estuary } \\
\text { River Pyhajoki }\end{array}$ & $\mathbf{4}$ & $20 \pm 2.5$ & $11.4 \pm 5.6$ & $0.02 \pm 0.01$ & $16 \pm 2.0$ & $-0.3 \pm 0.2$ & $3.0 \pm 0.8$ & $5.3 \pm 0.1$ \\
$\begin{array}{l}\text { Estuary } \\
\text { River Kalajoki }\end{array}$ & $\mathbf{4}$ & $24 \pm 4.1$ & $13.6 \pm 4.3$ & $0.6 \pm 0.5$ & $20 \pm 4.11$ & $-0.4 \pm 0.2$ & $0.9 \pm 0.1$ & $5.6 \pm 0.2$ \\
Estuary & 4 & $27 \pm 5.8$ & $15.6 \pm 6.7$ & $2.3 \pm 2.2$ & $21 \pm 5.7$ & $-0.4 \pm 0.2$ & $1.2 \pm 0.4$ & $5.5 \pm 0.1$ \\
\hline
\end{tabular}


1 Figure legends

2

3 Figure 1. A) Denitrification in the rivers Temmesjoki (1), Siikajoki (2), Pyhäjoki (3)

4 Kalajoki (4), in the Paimionlahti Bay (5) and in the Ahvenkoskenlahti Bay (6). Black

5 columns; total denitrification (Dtot). Numbers; the percentage of coupled nitrification-

6 denitrification (Dn) of the total denitrification (Dtot). B) Black columns; Dn, white

7 columns; Dw in the Paimionlahti Bay and C) in the Ahvenkoskenlahti Bay. Averages

8 and standard deviations shown. The circled sites are inside the estuary.

9

10

11

12

13

14

15

16

17

18

19

20

21

22

23 